\title{
Bond of High Strength Concrete with High Strength Reinforcing Steel
}

\author{
Muhammad N.S. Hadi*
}

Faculty of Engineering, University of Wollongong, Wollongong 2522, Australia

\begin{abstract}
This paper presents a study about the bond of high strength concrete with high strength steel. Fourteen pull out tests were carried out to determine the bond. The concrete strength was about $70 \mathrm{MPa}$ and the steel was a $500 \mathrm{MPa}$ grade. Bar diameters used were 12,16, 20, 25, 28, 32 and $36 \mathrm{~mm}$. In order to investigate the effect of cover, each test was done twice, once in a $240 \mathrm{~mm}$ diameter concrete cylinder and the second in a $300 \mathrm{~mm}$ diameter cylinder. Based on the test results a new equation representing the bond is proposed.
\end{abstract}

Key Words: Reinforced concrete, Bond, High strength concrete, High strength steel.

\section{RESEARCH SIGNIFICANCE}

High strength concrete is being more widely used in the last few years. More recently, new $500 \mathrm{MPa}$ reinforcing steel has been introduced. Most design guides are limited to concrete up to $50 \mathrm{MPa}$ or so compressive strength and reinforcing steel of $400 \mathrm{MPa}$ tensile strength. This paper is a step in understanding the behaviour of one aspect of high strength concrete reinforced with high strength steel.

\section{INTRODUCTION}

In many countries, high strength concrete has become popular in recent years. High strength concrete is undergoing widespread use in civil engineering and construction processes today. The strength of concrete up to $130 \mathrm{MPa}$ has been used popularly for overseas projects while concrete up to $100 \mathrm{MPa}$ has been used in some Australian projects. The benefits of increased strength, smaller dimensions and lower volumes would see its immediate application into design. In the last few years, a draft standard incorporating the use of high strength $500 \mathrm{MPa}$ steel to the construction industry was introduced. The use of high strength steel provides smaller cross sections and a solution to congestion problems. The benefit of the increase in steel strength, includes providing stronger structural members and decreasing the dead load of members. The scope of the Australian Standards for Concrete Structures, AS 3600 [1] is limited to concrete with strength less than $50 \mathrm{MPa}$ and reinforcing steel of $400 \mathrm{MPa}$ strength. Hence, there is a need to investigate many aspects of the behaviour and interaction of high strength concrete and high strength steel and propose design rules and limitations for their use. This paper is a step in this direction.

In order to investigate the bond strength of high strength steel bars with high strength concrete, pullout tests were conducted. These tests were conducted on 14 specimens with concrete compressive strength of about $70 \mathrm{MPa}$ while the tensile steel was greater than $500 \mathrm{MPa}$.

\footnotetext{
*Address correspondence to this author at the Faculty of Engineering, University of Wollongong, Wollongong 2522, Australia; Tel: +61 24221 4762; Fax: +61 24221 3238; E-mail: mhadi@uow.edu.au
}

\section{BEHAVIOUR OF BOND}

The transfer of axial force from a reinforcing bar to the surrounding concrete results in the development of tangential stress components along the contact surface. The stress acting parallel to the bar along the interface is called bond stress [2]. For reinforced concrete to function effectively as a composite material it is necessary for the reinforcing steel to be bonded to the surrounding concrete. Bond ensures that there is little or no slip of the steel relative to the concrete and the means by which stress is transferred across the steel-concrete [3].

Bond resistance is made up of chemical adhesion, friction and mechanical interlock between the bar and surrounding concrete. In the plain bars, only the first two of these components contribute to the bond strength. In the deformed bars, the surface protrusions or ribs interlocking with and bearing against the concrete key formed between the ribs contribute more positively to bond strength, and is the major reason for their superior bond effectiveness [2].

Fig. (1) illustrates the equilibrium conditions for portion of a reinforcing bar of length $d x$. The bond stress $u$ can be expressed as the change in the stress in the reinforcement over the length $d x$ as follows [4]:

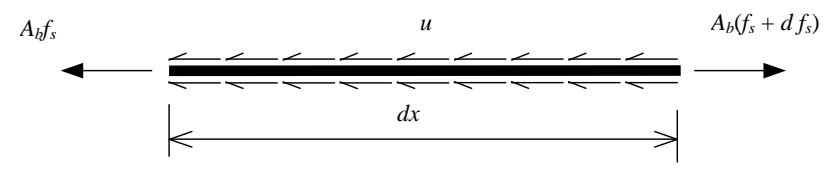

Fig. (1). Bond stress acting on a reinforcing bar.

$u\left(\pi d_{b} d x\right)=A_{b}\left(f_{s}+d f_{s}\right)-A_{b} f_{s}$

and hence

$u=\frac{A_{b} d f_{s}}{\pi d_{b} d x}=\frac{d_{b} d f_{s}}{4 d x}$

where $A_{b}$ is the area of bar, $d_{b}$ is the bar diameter, and $f_{s}$ is the stress in the bar.

For uniform bond, the bond stress can be expressed as:

$u=\frac{P_{\max }}{\pi d_{b} L_{d}}$ 
where $P_{\max }=$ maximum pullout load, $d_{b}=$ diameter of the bar and $L_{d}$ is the embedded bar length.

Several researchers have attempted to formulate equations that represent the bond between the reinforcing bars and the concrete. Below is a brief description of a few:

Orangun et al. [5] proposed the following formula:

$u=0.083045 \sqrt{f_{c}^{\prime}}\left[1.2+3 \frac{c}{d_{b}}+50 \frac{d_{b}}{L_{d}}\right]$

where $c=$ minimum concrete cover, $\mathrm{mm}$ and $f^{\prime}{ }_{c}$ is the concrete compressive strength, MPa.

Darwin et al. [6] proposed a modified expression (in SI) for bond strength as follows: the strain value during the tensile test. The change in length in millimeters was recorded at test completion. The experimental results are shown in Table $\mathbf{1}$. As the results of tensile test show that the bars were able to produce high value of strength in every specimens, except in the case of $32 \mathrm{~mm}$ bars where the bar failed suddenly during the test.

The average compressive strength of the concrete used in the pull out tests is $70.9 \mathrm{MPa}$

All the pullout specimens were constructed by using moulds made of PVC pipes (Fig. 3). Two sizes of the PVC pipes were used, which were $240 \times 300 \mathrm{~mm}$ (denoted as A specimens) and $300 \times 300 \mathrm{~mm}$ (denoted as B specimens) cylinders. The PVC pipes were cut into seven specimens for each size by the use of a cutting machine. The fourteen pipes were cleaned and the cut surface was smoothed by using a

$$
u=0.083045 \sqrt{f_{c}^{\prime}}\left[\left(1.06+2.12 \frac{c}{d_{b}}\right)\left(0.92+0.08 \frac{C_{\max }^{*}}{C_{\min }}\right)+75 \frac{d_{b}}{L_{d}}\right]
$$

where $C=\min \left(C_{x}, C_{y}, C_{s} / 2\right)$ and, $C_{\max }^{*}=\max \left[\min \left(C_{x}, \frac{C_{s}}{2}\right), C_{y}\right]$ in which $C_{x}$ is the side cover, $C_{y}$ is the bottom cover and $C_{s}$ is the spacing between the bars.

Australian Standard 3600 [1] recommends the following equation:

$u=0.265 \sqrt{f_{c}^{\prime}}\left(\frac{c}{d_{b}}+0.5\right)$

Esfahani and Rangan [7] proposed the following formula for high strength concrete with compressive equal to or greater than $50 \mathrm{MPa}$ :

$u=8.6 \frac{C / d_{b}+0.5}{C / d_{b}+5.5} f_{c t}$

where $C$ is the minimum cover and $f_{c t}$ is the tensile strength of concrete taken as $0.55 \sqrt{f_{c}^{\prime}}$, in MPa.

\section{PULLOUT SPECIMEN FABRICATION}

In order to test the viability of the above formulas and their applicability for high strength concrete and high strength steel, fourteen pullout test specimens were produced to determine the bond between high strength concrete and high strength steel bar. All of the pullout specimens were made on the same day at the University of Wollongong laboratory. The high strength concrete used in construction was provided by industry. All the steel bars were 500 grade steel with nominal diameters of 12, 16, 20, 25, 28, 32, $36 \mathrm{~mm}$. For each bar size two concrete sizes ( 240 and $300 \mathrm{~mm}$ diameter) were conducted. Fig. (2) shows details of the test specimens.

Before conducting the pull-out tests, all reinforcing bars were tested for their tensile strength. Bars with the diameters $12,16,20,25$, and $28 \mathrm{~mm}$ were tested at the University of Wollongong and those with 32 and $36 \mathrm{~mm}$ diameter were tested at the University of New South Wales. One strain gauge was placed on each size of the bar surface to measure file on the surface. All fourteen pipes were placed on a special wooden board, which was $650 \mathrm{~mm}$ wide by $2400 \mathrm{~mm}$ deep by using four brackets for each specimen. Screws were used to fix all the pipes on the board after the pipes were

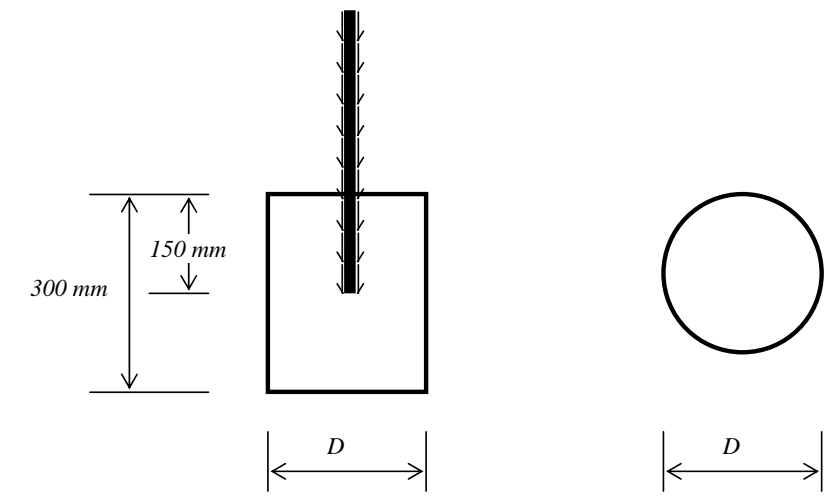

Fig. (2). Details of test specimens $(D=240 \mathrm{~mm}$ in group A specimens, $=300 \mathrm{~mm}$ in Group B specimens).

arranged parallel to each other on the board. Two square iron bars were prepared for holding the reinforcing bars by the use of brackets (Fig. 4). Before pouring the concrete into the pullout test moulds, the moulds were oiled around the moulds surface and at the bottom of the moulds. The concrete was poured into the PVC moulds in three layers. Each layer of the poured concrete was vibrated thoroughly with the penetrating vibrator placed vertically into the specimen and slowly removed. A $25.4 \mathrm{~mm}$ diameter-penetration vibrator was used for compacting the concrete. After the poured concrete was compacted properly, two square bars were placed on the short steel columns for holding the reinforcing bars vertically above the concrete specimens. One bar was placed into the fresh concrete specimen and embedded for $150 \mathrm{~mm}$ depth in the concrete. The reinforcing bars were approximately $600 \mathrm{~mm}$ length. Before using the bars, the external (free) end of each bar was threaded by the use of lathe for placing a nut. This nut would resist the loading during the pullout test. 
Table 1. Results of Tensile Strength of the Bars

\begin{tabular}{|c|c|c|c|c|}
\hline Bar Nom. Dia. mm & Ave. Bar Core Dia.mm & Yield Load kN & Ultimate Load kN & Yield Stress MPa \\
\hline \hline 12 & 11.0 & 58.7 & 68.72 & 124.10 \\
16 & 15.7 & 106.3 & 202.20 & 519.0 \\
20 & 19.4 & 174.0 & 297.00 & 522.0 \\
25 & 24.5 & 256.0 & 393.50 & 53.8 \\
28 & 27.5 & 331.0 & 450.60 & 537.55 \\
32 & 31.5 & 365.0 & 648.20 & 53.8 \\
\end{tabular}

The pullout test specimens were cured by covering with wet Hessian bags, and kept moist by replenishing the water every day for approximately ten days. The PVC moulds were taken out after ten days and the specimens were kept moist by covering with plastic until 28 days. The cylinders, which were cast to determine the compressive strength were taken at the same day and cured in the water tank for 28 days.

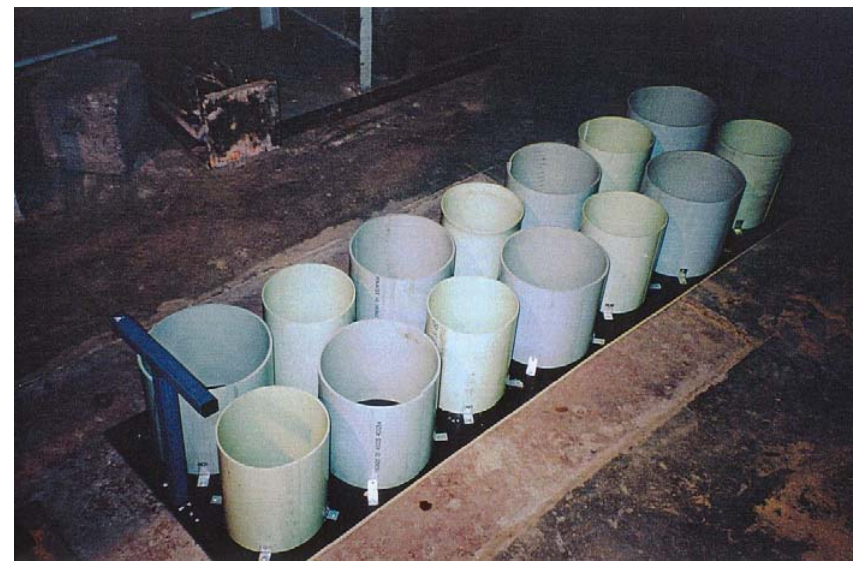

Fig. (3). Moulds used in the experimental programme.

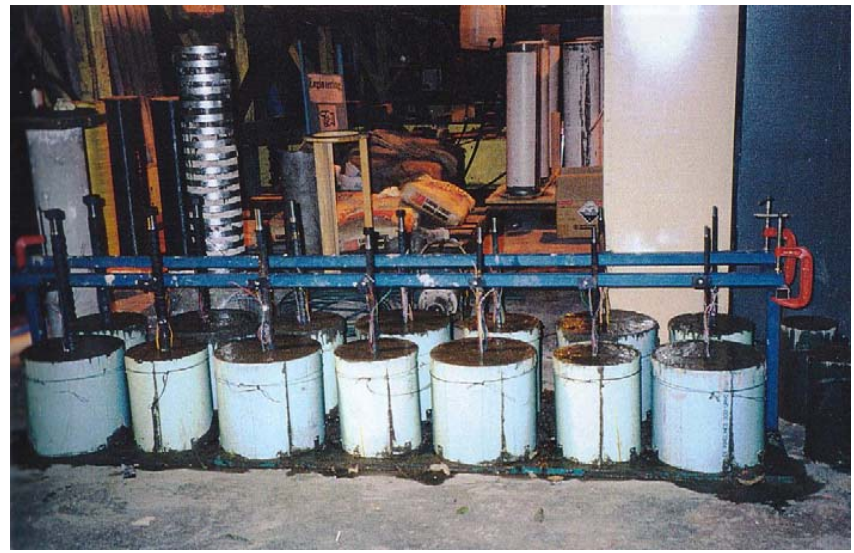

Fig. (4). Casting the specimens.

\section{TESTING}

The pullout test specimens were loaded by the hollow hydraulic machine, which has maximum loading 30 tons $(300 \mathrm{kN})$. The hollow hydraulic machine was installed with Enerpac hydraulic hand-pump machine. The source of loading equipment and the load cell connected with strain indicator were used for the pullout test in 12A, 12B, 16A, 16B,
20A, 20B, 25A and 25B specimens. In the other specimens, which were 28A, 28B, 32A, 32B, 36A and 36B, the Enerpac $\mathrm{RCH}-603$ was used for loading due to the bar size of these specimens which were unable to be fitted with the hollow hydraulic machine. The maximum load of Enerpac RCH-603 is 60 tons $(600 \mathrm{kN})$. The pullout test set up is presented in Figs. 5 and 6. A dial gauge was used to measure the slip of the bar from the concrete. The dial gauge was fixed onto the load cell and the displacement was measured of the top off the loading equipment.

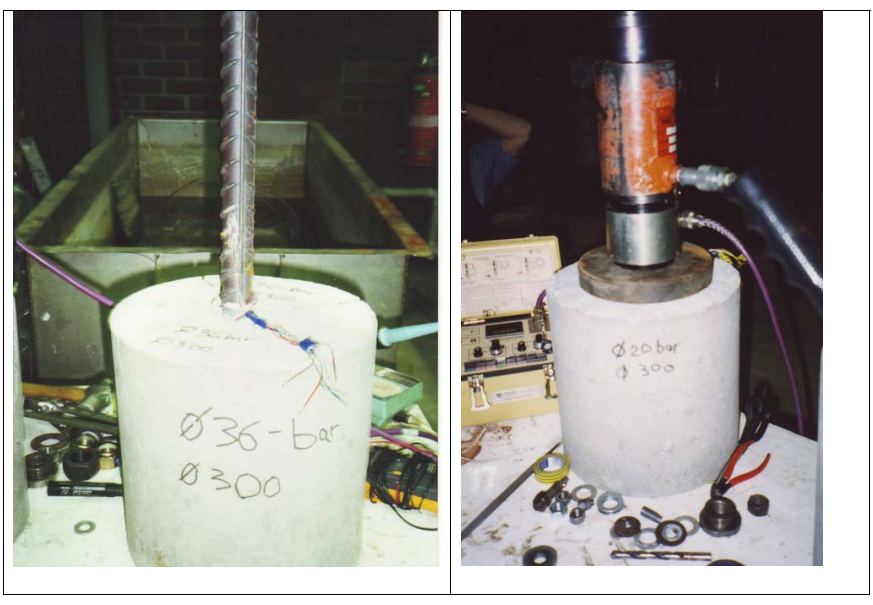

Fig. (5). Testing the specimens.

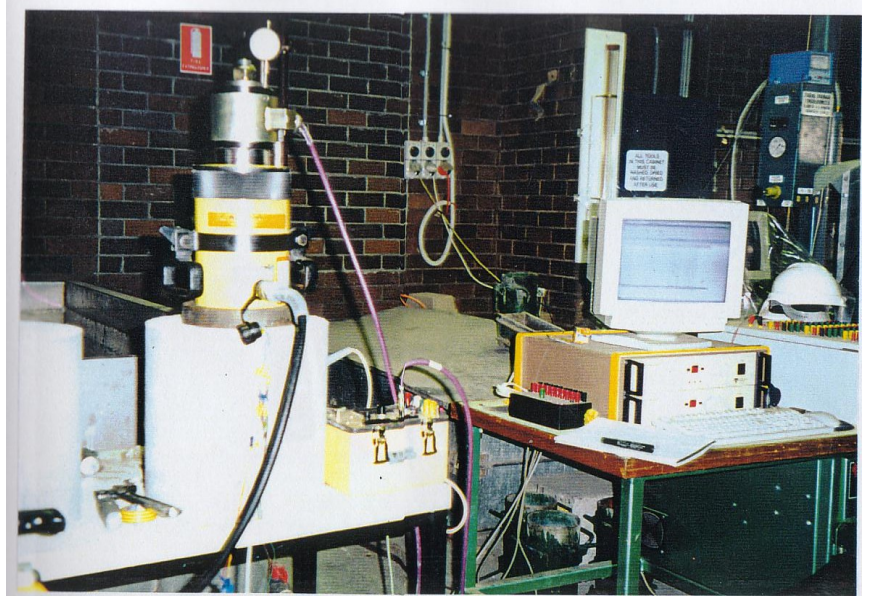

Fig. (6). Test set up.

\section{RESULTS}

The fourteen pullout specimens were divided into two groups according to the concrete cover of the specimen, the 
first group, denoted as A, had about $120 \mathrm{~mm}$ (cylinder diameter $240 \mathrm{~mm}$ ) concrete cover and the second group, denoted as B, had about $150 \mathrm{~mm}$ cover (cylinder diameter 300 $\mathrm{mm}$ ) with seven specimens for each group. The high strength bar diameters were $12,16,20,25,28,32$ and $36 \mathrm{~mm}$ for each group. The embedded length of the bar was $150 \mathrm{~mm}$ from the top side of the concrete specimen. The test results and details are presented in Table $\mathbf{2}$. The bond stress for the pullout test was obtained by Equation 3. Also the equations of Orangun et al. [5], Darwin et al. [6], the Australian Standard 3600 [1] and Esfahani and Rangan [7] were used to calculate the bond strength. All these bond results are presented in Table 2.

The pullout test specimens failed by the following three modes of failures, pullout failure (P), splitting failure of the tested specimen (S) and steel rupture failure (CS). The pullout failure mode occurred when the concrete cover provided adequate confinement, thus preventing a splitting failure of the test specimen. The bond strength was mainly controlled by the capacity of the concrete specimen. The pullout failure was observed only in $300 \mathrm{~mm}$ diameter specimen with a 12 $\mathrm{mm}$ bar and was characterized by cracks on the top loaded face only. Splitting failure mode was the predominant type of failure of the tested specimen. It was characterised by splitting of the concrete specimen in a brittle mode of failure. Both transverse and longitudinal cracks were observed at failure.

The results of the pullout test show that the maximum bond stress value occurred in $16 \mathrm{~B}$ and $20 \mathrm{~B}$ specimens. The minimum bond stress value occurred in specimen $36 \mathrm{~A}$, which used the biggest reinforcing bar for the experiments.
The bond strength increased with the smaller bar sizes and the bigger concrete cover specimens.

Based on the measured bond strength for all the specimens and in order to take into account the higher strength of both the concrete and the reinforcing steel, a new formula is proposed. The formula is similar to the formula of Orangun et al. [5], which is shown in Equation 4. Statistical analysis is used to best fit the data. Based on this analysis, the following formula is proposed:

$$
u=0.083045 \sqrt{f_{c}^{\prime}}\left[22.8-0.208 \frac{c}{d_{b}}-38.212 \frac{d_{b}}{L_{d}}\right]
$$

Application of the new proposed formula to the test results of this study is presented in Table 2 . Next the measured bond strengths together with the calculated ones based on the formulas of Orangun et al. [5], Darwin et al. [6], the Australian Standard 3600 [1] and Esfahani and Rangan [7] as well as the proposed formula are compared. These comparisons are presented for the $240 \mathrm{~mm}$ specimens in Fig. (7) and those for the $300 \mathrm{~mm}$ specimens in Fig. (8).

\section{CONCLUSIONS}

Based on the test results of fourteen pullout specimens, it can be stated that the pullout specimen with the smaller bar size has greater bond strength than the specimen with the larger diameter bar and the pullout test results also indicated that the bond strength and the initial stiffness increased as the amount of concrete surrounding the reinforcing bar increased. The maximum bond stress value occurred in specimens $16 \mathrm{~B}$ and $20 \mathrm{~B}$ whereas the minimum bond stress value was in specimen $36 \mathrm{~A}$.

Table 2. Summary of the Pullout Test Results

\begin{tabular}{|c|c|c|c|c|c|c|c|c|c|c|}
\hline \multirow[t]{2}{*}{ Spec. } & \multirow{2}{*}{$\begin{array}{r}\text { Bar } \\
\text { Core } \\
\text { Dia. } \\
\\
\text { mm }\end{array}$} & \multirow{2}{*}{$\begin{array}{l}\text { Cylinder } \\
\text { dia./len. } \\
\text { mm/mm }\end{array}$} & \multirow{2}{*}{$\begin{array}{l}\text { Failure } \\
\text { Mode* }\end{array}$} & \multirow{2}{*}{$\begin{array}{l}\mathbf{P}_{\max } \\
\mathbf{k N}\end{array}$} & \multirow{2}{*}{$\begin{array}{c}\text { Measured } \\
\text { Bond } \\
\text { Stress } \\
\text { MPa }\end{array}$} & \multicolumn{5}{|c|}{ Calculated Bond Strength MPa } \\
\hline & & & & & & $\begin{array}{c}\text { Orangun } \\
\text { et al. } \\
{[5]}\end{array}$ & $\begin{array}{c}\text { Darwin } \\
\text { et al. } \\
{[6]}\end{array}$ & $\begin{array}{c}\text { AS3600 } \\
{[1]}\end{array}$ & $\begin{array}{c}\text { Esfahani } \\
\text { and Rangan } \\
{[7]}\end{array}$ & $\begin{array}{c}\text { Proposed } \\
\text { Formula }\end{array}$ \\
\hline $12 \mathrm{~A}$ & 11 & $240 / 300$ & $\mathrm{CS}$ & 50 & 9.6 & 25.2 & 20.0 & 24.3 & 27.3 & 12.5 \\
\hline $16 \mathrm{~B}$ & 15.7 & $300 / 300$ & $\mathrm{CS}$ & 100 & 13.5 & 23.5 & 19.7 & 21.3 & 19.7 & 11.8 \\
\hline $20 \mathrm{~A}$ & 19.5 & $240 / 300$ & $\mathrm{~S}$ & 110 & 12.0 & 17.2 & 15.9 & 13.7 & 18.6 & 11.6 \\
\hline $20 \mathrm{~B}$ & 19.1 & $300 / 300$ & $\mathrm{~S}$ & 120 & 13.3 & 20.7 & 18.3 & 17.5 & 17.3 & 11.5 \\
\hline $28 \mathrm{~B}$ & 27.5 & $300 / 300$ & S & 155 & 12.0 & 17.6 & 17.7 & 12.2 & 24.3 & 10.3 \\
\hline $32 \mathrm{~A}$ & 31.3 & $240 / 300$ & S & 130 & 8.8 & 15.1 & 16.6 & 8.6 & 21.9 & 9.9 \\
\hline $32 \mathrm{~B}$ & 31.5 & $300 / 300$ & S & 150 & 10.1 & 17.1 & 18.1 & 10.6 & 20.8 & 9.7 \\
\hline $36 \mathrm{~A}$ & 35.3 & $240 / 300$ & $S$ & 115 & 6.9 & 15.1 & 17.4 & 7.6 & 19.4 & 9.2 \\
\hline
\end{tabular}

* $\mathrm{CS}=$ steel rupture failure, $\mathrm{P}=$ pullout failure, $\mathrm{S}=$ splitting failure. 


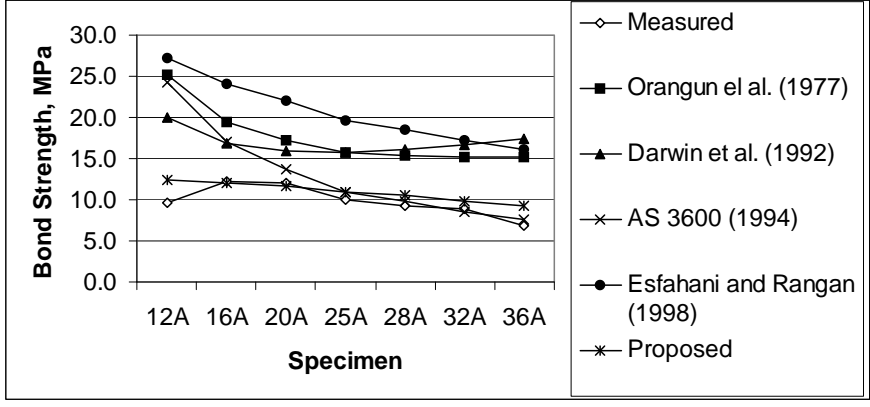

Fig. (7). Comparison of the bond strength for the $240 \mathrm{~mm}$ specimens.

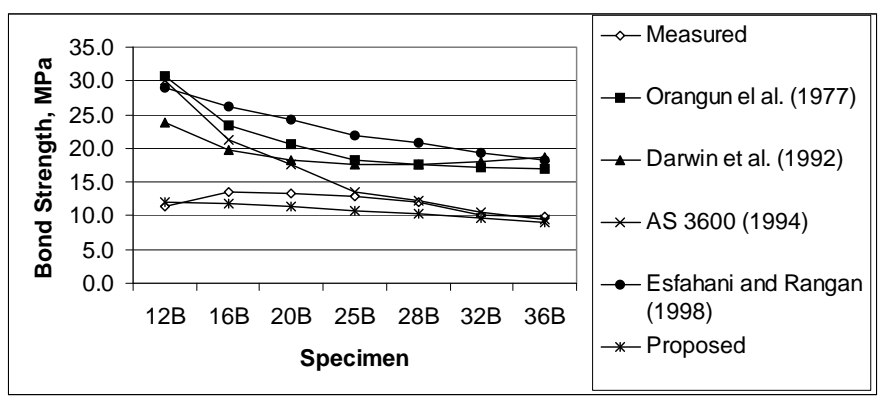

Fig. (8). Comparison of the bond strength for the $300 \mathrm{~mm}$ specimens.

For the pullout specimen failing, the predominant mode of failure of eleven of the tested specimens was splitting failure. The pullout failure only occurred in one specimen with the $12 \mathrm{~mm}$ bar with $300 \mathrm{~mm}$ cylinder and was characterized by cracks on the top loaded face only due to the adequate confinement of concrete cover. For the two specimens with the mode of steel rupture failure, the test specimens were broken by the exceeding load of the ultimate load of the reinforcing bar.

Based on the fourteen pull out tests, a new formula for the bond between high strength concrete and high strength steel is proposed.

\section{ACKNOWLEDGEMENT}

The author would like to express his gratitude for the financial assistance from the University of Wollongong through their Small Research Grant Scheme, which helped in conducting this research.

\section{LIST OF NOTATIONS}

\begin{tabular}{|c|c|c|}
\hline$A_{b}$ & $=$ & $\begin{array}{l}\text { Nominal cross-section area of reinforcing } \\
\text { bar }\end{array}$ \\
\hline $\mathrm{A}_{\mathrm{st}}$ & $=$ & Area of tensile reinforcement $\left(\mathrm{mm}^{2}\right)$ \\
\hline c & $=$ & Concrete cover \\
\hline $\mathrm{C}_{\max }^{*}$ & $=$ & $\begin{array}{l}\text { The highest of the lowest of } \mathrm{C}_{\mathrm{x}} \text { and } \mathrm{C}_{\mathrm{s}} / 2 \\
\text { and } \mathrm{C}_{\mathrm{y}}\end{array}$ \\
\hline $\mathrm{C}_{\min }$ & $=$ & The smallest of $\mathrm{C}_{\mathrm{x}}, \mathrm{C}_{\mathrm{y}}, \mathrm{C}_{\mathrm{s}} / 2$ \\
\hline $\mathrm{C}_{\mathrm{s}}$ & $=$ & Spacing between the bars. \\
\hline $\mathrm{C}_{\mathrm{x}}$ & $=$ & Side cover \\
\hline $\mathrm{C}_{\mathrm{y}}$ & $=$ & Bottom cover \\
\hline$d_{b}$ & $=$ & Nominal diameter of the bar \\
\hline $\mid x$ & $=$ & Short length of beam \\
\hline $\mathrm{f}_{\mathrm{c}}$ & $=$ & $\begin{array}{l}\text { Characteristic compressive strength of } \\
\text { concrete }\end{array}$ \\
\hline 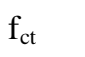 & $=$ & Tensile strength of concrete \\
\hline & $=$ & Maximum stress in bar \\
\hline$=$ & $=$ & Yield stress of steel reinforcing bar \\
\hline 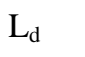 & $=$ & Embedded length of reinforced bar $\mathrm{db}$ \\
\hline $\operatorname{nax}$ & $=$ & Maximum pullout load \\
\hline & $=$ & Bond stress of the bar surface \\
\hline
\end{tabular}

\section{REFERENCES}

[1] Australian Standard for Concrete Structures. AS3600, North Sydney, Australia, 1994

[2] S. U. Pillai, and D. W. Kirk, Reinforced Concrete Design in Canada, McGraw-Hill, 1983.

[3] R. F. Warner, B. V. Rangan, A. S. Hall, and K. A. Faulkes, Concrete Structures, Longman, Australia, 1998.

[4] H. H. Abrishami, and D. Mitchell, "Simulation of Uniform Bond Stress", ACI Materials Journal, vol.89, No. 2, pp. 161-168, MarchApril 1992.

[5] C. O. Orangun, I. O. Jirsa, and J. E. Breen, "A Reevaluation of Test Data on Development Length and Splices", ACI Journal, vol. 74, no. 3, pp. 114-122, March 1977.

[6] D. Darwin, S. L. McCabe, E. K. Idun, and S. P. Schoenekase, "Development Length Criteria: Bars Not Confined by Transverse Reinforcement", ACI Structural Journal, vol. 89, no. 6, pp. 709-720, Nov.-Dec. 1992.

[7] M. R. Esfahani and B. V. Rangan, "Bond Between Normal Strength and High-Strength Concrete (HSC) and Reinforcing Bars in Splices in Beams", ACI Structural Journal, vol. 95, no. 3, pp. 272280, May-Jun. 1998. 